\title{
NOTES
}

\section{Polymerization of 6-Bromo-1-hexyne and 1,6-Dibromo-1-hexyne ${ }^{\dagger}$}

\author{
Masaaki KAWASAKI, Toshio Masuda, and Toshinobu HigashimURA \\ Department of Polymer Chemistry, Kyoto University, \\ Kyoto 606, Japan
}

(Received May 30, 1983)

\begin{abstract}
KEY WORDS Coordination Polymerization / Transition Metal Catalyst / 6-Bromo-1-hexyne / 1,6-Dibromo-1-hexyne / Menschutkin Reaction /
\end{abstract}

Ziegler-type catalysts have been used most frequently for the polymerization of acetylenes. ${ }^{2}$ Apart from this, we found that catalysts based on molybdenum (Mo) and tungsten (W) are effective for the polymerization of various acetylenes such as aromatic, ${ }^{3}$ aliphatic, ${ }^{4}$ and oxygen-containing ${ }^{1}$ acetylenes.

Bromine-containing aliphatic acetylenes are interesting with regard to the following aspects: i) when a bromine exists at the end of an alkyl substituent, reactions of this bromine following polymrization are possible, leading to new polymers; ii) if a bromine exists adjacent to the triple bond, it will greatly affect the monomer reactivity and polymer properties.

The present study deals with the polymerization of two kinds of bromine-containing acetylenes (6bromo-1-hexyne and 1,6-dibromo-1-hexyne). Further, water-soluble conjugated polyene polymers were synthesized by the Menschutkin reaction of these bromine-containing polymers.

\section{EXPERIMENTAL}

6-Bromo-1-hexyne and 1,6-dibromo-1-hexyne were donated by Shin-Etsu Chemical Co., Ltd. 6Bromo-1-hexyne: bp $36-38^{\circ} \mathrm{C} / 3 \mathrm{mmHg}$, purity 97\%; 1,6-dibromo-1-hexyne: bp $114^{\circ} \mathrm{C} / 10 \mathrm{mmHg}$, purity $96 \%$. Catalysts and cocatalysts were commercially obtained and employed without further purification. Two-component catalysts $\left[\mathrm{MoCl}_{5}-\right.$
$\mathrm{Ph}_{4} \mathrm{Sn}(1: 1), \mathrm{WCl}_{6}-\mathrm{Ph}_{4} \mathrm{Sn}(1: 1), \mathrm{Fe}(\mathrm{acac})_{3}-\mathrm{Et}_{3} \mathrm{Al}$ $(1: 3)$ and $\left.\mathrm{Ti}(\mathrm{O} n-\mathrm{Bu})_{4}-\mathrm{Et}_{3} \mathrm{Al}(1: 4)\right]$ were prepared by mixing the catalyst components in a toluene solution and aging the mixtures at $30^{\circ} \mathrm{C}$ for $15 \mathrm{~min}$. The method of preparing metal carbonyl catalysts $\left[\mathrm{Mo}(\mathrm{CO})_{6}-\mathrm{CCl}_{4}-h v, \mathrm{~W}(\mathrm{CO})_{6}-\mathrm{CCl}_{4}-h v\right]$ has been described elsewhere. ${ }^{3}$ Polymerization was carried out under dry nitrogen. Monomer conversions and yields of methanol-insoluble polymers were determined by gas chromatography and gravimetry, respectively. IR and NMR spectra were recorded on Shimadzu IR27G and JEOL FX90Q spectrometers, respectively.

\section{RESULTS AND DISCUSSION}

\section{Polymerization}

6-Bromo-1-hexyne possesses only one bromine at the end of the alkyl substituent. When three Mobased catalysts $\left[\mathrm{MoCl}_{5}, \quad \mathrm{MoCl}_{5} \cdot \mathrm{Ph}_{4} \mathrm{Sn}\right.$, and $\left.\mathrm{Mo}(\mathrm{CO})_{6}-\mathrm{CCl}_{4}-h v\right]$ were used for the polymerization of this monomer, the yields of the methanolinsoluble polymer were low (see Table I). On the other hand, the corresponding W-based catalysts $\left[\mathrm{WCl}_{6}, \mathrm{WCl}_{6}-\mathrm{Ph}_{4} \mathrm{Sn}(1: 1)\right.$, and $\left.\mathrm{W}(\mathrm{CO})_{6}-\mathrm{CCl}_{4}-h v\right]$ provided the polymer in good yields. $\mathrm{WCl}_{6}$ achieved the highest polymer yield $(\sim 60 \%)$. When two Ziegler catalysts, $\mathrm{Fe}(\mathrm{acac})_{5}-\mathrm{Et}_{3} \mathrm{Al}(1: 3)$ and $\mathrm{Ti}(\mathrm{O} n$ $\mathrm{Bu}_{4}-\mathrm{Et}_{3} \mathrm{Al}(1: 4)$, which are known to polymerize acetylene, ${ }^{2}$ were used for comparison, hardly any methanol-insoluble polymer was obtained.

\footnotetext{
† Part II of "Polymerization of Heteroatom-Containing Acetylenes." For Part I, see ref 1.
} 
Table I. Polymerization of bromine-containing acetylenes by various catalysts ${ }^{\mathrm{a}}$

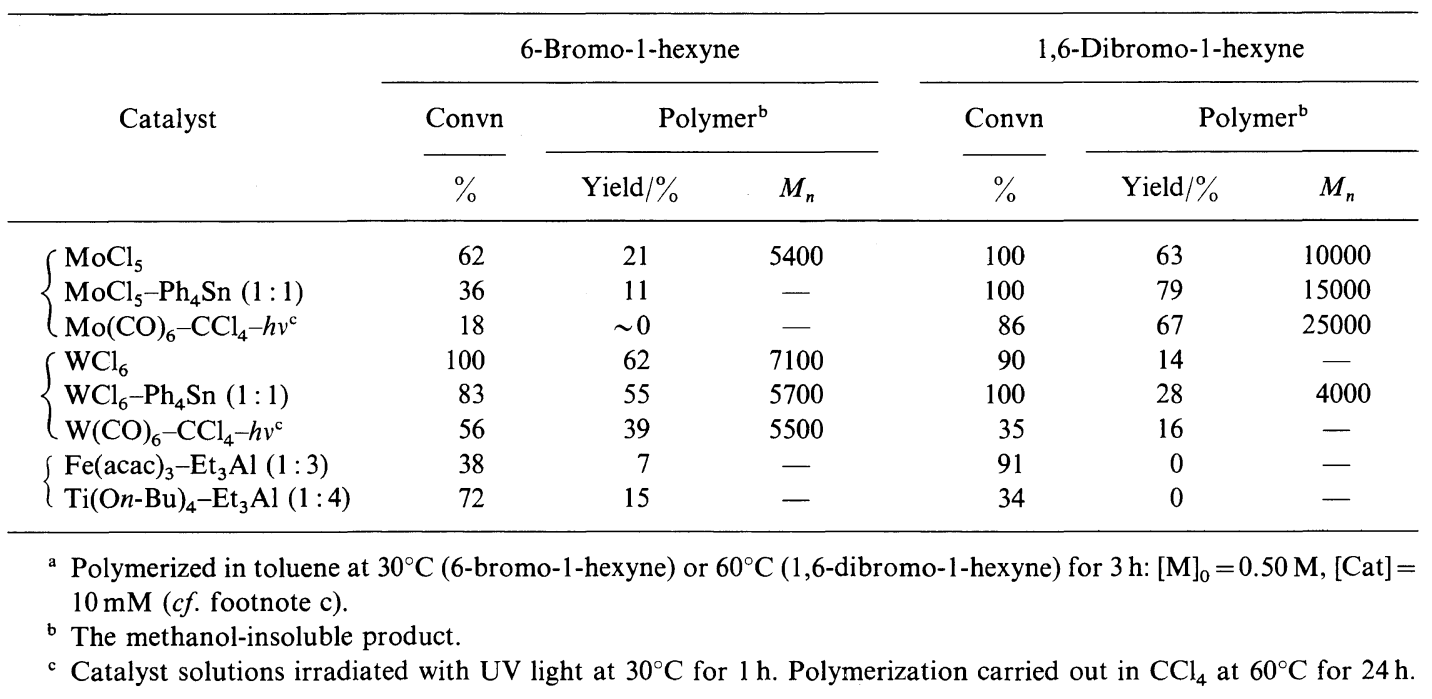

Table II. Solvent effect on the polymerization of bromine-containing acetylenes ${ }^{\text {a }}$

\begin{tabular}{|c|c|c|c|c|c|c|}
\hline \multirow{3}{*}{ Solvent } & \multicolumn{3}{|c|}{ 6-Bromo-1-hexyne } & \multicolumn{3}{|c|}{ 1,6-Dibromo-1-hexyne } \\
\hline & \multirow{2}{*}{$\frac{\text { Convn }}{\%}$} & \multicolumn{2}{|c|}{ Polymer ${ }^{b}$} & \multirow{2}{*}{$\frac{\text { Convn }}{\%}$} & \multicolumn{2}{|c|}{ Polymer ${ }^{b}$} \\
\hline & & Yield $/ \%$ & $M_{n}$ & & Yield $/ \%$ & $M_{n}$ \\
\hline \{ Toluene & 100 & 62 & 7100 & 100 & 79 & 15000 \\
\hline Tetralin & 67 & 36 & 4800 & 100 & 81 & 13000 \\
\hline $\int \mathrm{CCl}_{4}$ & 100 & 65 & 9200 & 91 & 68 & 14000 \\
\hline$\left\{\left(\mathrm{CH}_{2} \mathrm{Cl}\right)_{2}\right.$ & 47 & 21 & 5500 & 95 & 38 & 4000 \\
\hline 1,4-Dioxane & 5 & 0 & - & 0 & 0 & - \\
\hline$\left(\mathrm{CH}_{3} \mathrm{OCH}_{2}\right)_{2}$ & 0 & 0 & - & 0 & 0 & - \\
\hline
\end{tabular}

a Polymerized by $\mathrm{WCl}_{6}$ at $30^{\circ} \mathrm{C}$ (6-bromo-1-hexyne) or by $\mathrm{MoCl}_{5}-\mathrm{Ph}_{4} \mathrm{Sn}(1: 1)$ at $60^{\circ} \mathrm{C}$ (1,6-dibromo-1-hexyne) for $3 \mathrm{~h}:[\mathrm{M}]_{0}=0.50 \mathrm{M},[\mathrm{Cat}]=10 \mathrm{mM}$.

b The methanol-insoluble product.

1,6-Dibromo-1-hexyne has two bromines, one at the end of the alkyl group and the other adjacent to the triple bond. The polymerization of this monomer with Mo-based catalysts afforded a methanol-insoluble polymer in high yields (Table I). The highest polymer yield $(\sim 80 \%)$ was attained using $\mathrm{MoCl}_{5}-\mathrm{Ph}_{4} \mathrm{Sn}(1: 1)$. The polymer was formed only in small amounts with W-based catalysts, and not at all with Ziegler catalysts.

Table II shows the solvent effect on the polymerization of these monomers. Based on the findings in Table I, $\mathrm{WCl}_{6}$ and $\mathrm{MoCl}_{5}-\mathrm{Ph}_{4} \mathrm{Sn}(1: 1)$ were employed as catalysts for the polymerization of 6- bromo-1-hexyne and 1,6-dibromo-1-hexyne, respectively. For both monomers, aromatic and halogenated hydrocarbons, especially those with low polarities, were favorable solvents. Polymers were not obtained in ethereal solvents such as 1,4-dioxane and 1,2-dimethoxyethane.

The maximum molecular weight of poly(6bromo-1-hexyne) was 9200 , which corresponds to a degree of polymerization (DP) of about 60 . The maximum value for poly(1,6-dibromo-1-hexyne) was 25000 (DP 100). Thus, the latter monomer produced a polymer with higher DP than did the former. Unless suitable catalysts and solvents were 
selected, not the methanol-insoluble polymers but methanol-soluble oligomers tended to form as the main products from both monomers.

In the polymerization of 1-hexyne, W-based catalysts are more active than Mo versions (the maximum molecular weight 4900; DP 60). ${ }^{5}$ Therefore, it is concluded that 6-bromo-1-hexyne behaves similarly to 1-hexyne in the Mo- and Wcatalyzed polymerization, while 1,6-dibromo-1hexyne in a different way. The electronic and/or steric effect of the bromine bonded to $\mathrm{C}_{1}$ in 1,6-dibromo-1-hexyne should be responsible for this different behavior.

\section{Structure and Properties of Polymers}

The analytical and spectral data of polymers are as follows: Poly(6-bromo-1-hexyne): Anal. Calcd for $\left(\mathrm{C}_{6} \mathrm{H}_{9} \mathrm{Br}\right)_{n}$ : $\mathrm{C}, 44.75 \% ; \mathrm{H}, 5.63 \% ; \mathrm{Br}, 49.62 \%$. Found: C, $45.02 \%$; H, $5.53 \%$; Br, $49.37 \%$. IR 3000 (m), $2950(\mathrm{~s}), 2850(\mathrm{~m}), 1650-1580(\mathrm{w}), 1450(\mathrm{~m})$, $1430(\mathrm{~m}), 1240(\mathrm{~m}), 750(\mathrm{~m}), 640(\mathrm{~m})$, and $550 \mathrm{~cm}^{-1}$ (m). ${ }^{1} \mathrm{H} \mathrm{NMR}\left(\mathrm{CDCl}_{3}\right) \delta 6.6-4.7$ (br s, $\left.1,-\mathrm{CH}=\right)$, $3.4\left(\mathrm{~s}, 2,-\mathrm{CH}_{2} \mathrm{Br}\right.$ ), and $2.6-1.5 \mathrm{ppm}$ (br s, 6, $\left.=\mathrm{CCH}_{2} \mathrm{CH}_{2} \mathrm{CH}_{2}-\right),{ }^{13} \mathrm{C}$ NMR $\left(\mathrm{CDCl}_{3}\right) \delta 134.0$ $\left(\mathrm{C}_{2}\right) 120.3\left(\mathrm{C}_{1}\right), 33.5\left(\mathrm{C}_{3}, \mathrm{C}_{6}\right)$ and $27.1 \mathrm{ppm}\left(\mathrm{C}_{4}, \mathrm{C}_{5}\right)$. Poly(1,6-dibromo-1-hexyne): Anal. Calcd for $\left(\mathrm{C}_{6} \mathrm{H}_{8} \mathrm{Br}_{2}\right)_{n}: \mathrm{C}, 30.04 \% ; \mathrm{H}, 3.36 \%$; $\mathrm{Br}, 66.60 \%$. Found: C, $30.62 \% ; \mathrm{H}, 3.34 \%$; $\mathrm{Br}, 65.89 \%$. IR 2950 (s), $2850(\mathrm{~m}), 1650-1570(\mathrm{w}), 1450(\mathrm{~m}), 1430(\mathrm{~m})$, $1280(\mathrm{~m}), 1240(\mathrm{~m}), 870(\mathrm{w}), 730(\mathrm{w})$, and $560 \mathrm{~cm}^{-1}$ (w). ${ }^{1} \mathrm{H} \mathrm{NMR}\left(\mathrm{CDCl}_{3}\right) \delta 3.4\left(\mathrm{~s}, 2,-\mathrm{CH}_{2} \mathrm{Br}\right), 2.8-$ $2.2\left(\mathrm{br} \mathrm{s}, 2,=\mathrm{CCH}_{2}-\right.$ ), and $2.2-1.4 \mathrm{ppm}$ (br s, 4, $\left.=\mathrm{CCCH}_{2} \mathrm{CH}_{2}-\right) \cdot{ }^{13} \mathrm{C}$ NMR $\delta 140.2\left(\mathrm{C}_{2}\right), 123.2$ $\left(\mathrm{C}_{1}\right), 33.1\left(\mathrm{C}_{3}, \mathrm{C}_{6}\right)$, and $26.0 \mathrm{ppm}\left(\mathrm{C}_{4}, \mathrm{C}_{5}\right)$. These spectral data support the following polymer structure formed without isomerization:

$$
+\mathrm{CX}=\stackrel{\mathrm{C}+{ }_{n}}{\stackrel{\mathrm{C}}{\mathrm{CH}_{2}} \mathrm{CH}_{2} \mathrm{CH}_{2} \mathrm{CH}_{2} \mathrm{Br} \quad(\mathrm{X}=\mathrm{H}, \mathrm{Br})}
$$

Poly(6-bromo-1-hexyne) was a dark brown, viscous, air-sensitive substance. Poly(1,6-dibromo-1hexyne) was a light brown, air-stable powder, showing a softening point at $183-192^{\circ} \mathrm{C}$ and a low electrical conductivity of $6 \times 10^{-14} \mathrm{~S} \cdot \mathrm{cm}^{-1}$. These differences in color, air-stability and softening point between both polymers are attributed to a twisted conformation of the main chain in poly $(1,6-$ dibromo-1-hexyne) caused by two side groups per repeating unit. Both polymers were soluble in aromatic and halogenated hydrocarbons, cyclic ethers etc., whereas insoluble in aliphatic hydrocarbons, diethyl ether and methanol.

\section{Polymer Reaction}

Water-soluble conjugated polyene polymers were synthesized by the Menschutkin reaction of these bromine-containing polymers. The reaction was carried out using triethylamine in $N, N$-dimethylformamide at $60^{\circ} \mathrm{C}$ for $24 \mathrm{~h}$ : [polymer] $=0.20 \mathrm{M}$ (per repeating unit), $\left[\mathrm{Et}_{3} \mathrm{~N}\right]=2.0 \mathrm{M}$.

The ${ }^{1} \mathrm{H}$ and ${ }^{13} \mathrm{C}$ NMR signals of the products are assigned as follows:

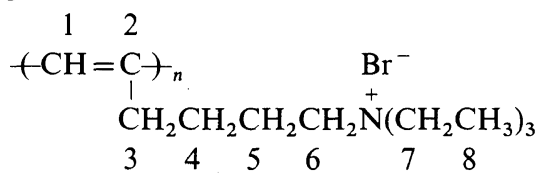

${ }^{1} \mathrm{H}$ NMR $\left(\mathrm{D}_{2} \mathrm{O}\right) \delta 6.6-4.7(\mathrm{br} \mathrm{s}, 1,-\mathrm{CH}=), 3.2[\mathrm{~s}$, 8, $\left.\mathrm{N}\left(\mathrm{CH}_{2}\right)_{4}\right], 1.6$ (br s, $6,=\mathrm{CCH}_{2} \mathrm{CH}_{2} \mathrm{CH}_{2}-$ ), and $1.1 \mathrm{ppm}\left(\mathrm{s}, 9,3 \mathrm{CH}_{3}\right) \cdot{ }^{13} \mathrm{C} \mathrm{NMR}\left(\mathrm{D}_{2} \mathrm{O}\right) 133.1$ $\left(\mathrm{C}_{2}\right), 119.0\left(\mathrm{C}_{1}\right), 57.4\left(\mathrm{C}_{6}\right), 53.7\left(3 \mathrm{C}_{7}\right), 34.5\left(\mathrm{C}_{3}\right)$, $26.2\left(\mathrm{C}_{4}\right), 22.8\left(\mathrm{C}_{5}\right)$, and $8.0 \mathrm{ppm}\left(3 \mathrm{C}_{8}\right)$.

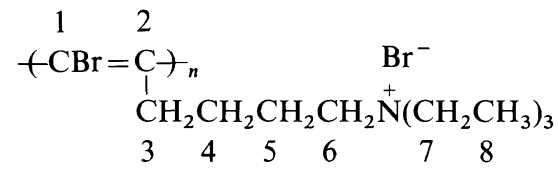

${ }^{1} \mathrm{H}$ NMR $\left.\left(\mathrm{D}_{2} \mathrm{O}\right) \delta 3.1\left[\mathrm{~s}, 8, \mathrm{~N}-\mathrm{CH}_{2}\right)_{4}\right], 1.4(\mathrm{br} \mathrm{s}, 6$, $=\mathrm{CCH}_{2} \mathrm{CH}_{2} \mathrm{CH}_{2}-$ ), and $1.1 \mathrm{ppm}\left(\mathrm{s}, 9,3 \mathrm{CH}_{3}\right) \cdot{ }^{13} \mathrm{C}$ $\operatorname{NMR}\left(\mathrm{D}_{2} \mathrm{O}\right) \delta 141.0\left(\mathrm{C}_{2}\right), 125.0\left(\mathrm{C}_{1}\right), 57.3\left(\mathrm{C}_{6}\right), 53.8$ $\left(3 \mathrm{C}_{7}\right), 33.7\left(\mathrm{C}_{3}\right), 24.1\left(\mathrm{C}_{4}\right), 22.8\left(\mathrm{C}_{5}\right)$, and $8.3 \mathrm{ppm}$ $\left(3 \mathrm{C}_{8}\right)$.

The NMR data indicate that the bromine bonded to the main-chain carbon in poly-1,6-dibromo-1hexyne) does not undergo the Menschutkin reaction. The conversions of the bromine at the end of the alkyl group were $95 \%$ or above for both bromine-containing polymers as revealed by the ${ }^{1} \mathrm{H}$ NMR spectra. Table III shows some properties of the present polymers. The stabilities were analogous to those of the starting polymers. In spite of the presence of quarternary ammonium salts, the polymers were hardly hygroscopic.

These polymers produced by the Menschutkin reaction are examples of rare polymers that possess conjugated polyene structures and dissolve in water.

Acknowledgements. The authors acknowledge the donation of the monomers by Shin-Etsu Chemical Co., Ltd., Japan. This research was sup- 
Table III. Menschutkin reaction of poly(bromohexynes)

\begin{tabular}{|c|c|c|c|c|c|}
\hline \multirow{3}{*}{ Product structure } & \multirow{3}{*}{$\frac{\text { Convn }^{a}}{\%}$} & \multicolumn{4}{|c|}{ Product properties } \\
\hline & & \multirow[b]{2}{*}{ Color } & \multirow[b]{2}{*}{ Soluble in } & \multirow[b]{2}{*}{ Insoluble in } & \multirow{2}{*}{$\frac{\text { Conductivity }}{\mathrm{ohm}^{-1} \mathrm{~cm}^{-1}}$} \\
\hline & & & & & \\
\hline$\left(\mathrm{CH}=\stackrel{\mathrm{C}-)_{n}}{\stackrel{\left(\mathrm{CH}_{2}-\right)_{4}}{ } \mathrm{~N}^{+} \mathrm{Et}_{3} \mathrm{Br}^{-}}\right.$ & 95 & Dark brown & $\begin{array}{l}\text { Water } \\
\text { Methanol }\end{array}$ & $\left\{\begin{array}{l}\text { Toluene } \\
\mathrm{CHCl}_{3}\end{array}\right.$ & - \\
\hline$\left(\mathrm{CBr}=\stackrel{\mathrm{L})_{n}}{L_{\left(\mathrm{CH}_{2}\right)_{4} \mathrm{~N}^{+} \mathrm{Et}_{3} \mathrm{Br}^{-}}}\right.$ & 97 & Beige & DMF & $\mathrm{Et}_{2} \mathrm{O}$ & $6 \times 10^{-7}$ \\
\hline
\end{tabular}

a With respect to the bromine at the end of the alkyl group.

ported in part by a Grant-in-Aid for Scientific Research from the Ministry of Education, Science and Culture (No. 57550566).

\section{REFERENCES}

1. T. Masuda, M. Kawai, and T. Higashimura, Polymer, 23, 744 (1982).
2. See, for a review, C. I. Simionescu and V. Percec, Prog. Polym. Sci., 8, 133 (1982).

3. T. Masuda, K. Yamamoto, and T. Higashimura, Polymer, 23, 1663 (1982), and preceding papers.

4. Y. Okano, T. Masuda, and T. Higashimura, Polym. $J ., 14,477$ (1982), and preceding papers.

5. T. Masuda, Y.-X. Deng, and T. Higashimura, Bull. Chem. Soc. Jpn., 56, 2798 (1983). 